\title{
A serum-dependent defect of neutrophil function in chronic mucocutaneous candidiasis
}

\author{
SM WALKER AND SJ URBANIAK
}

From the Immunology Division, Regional Blood Transfusion Centre, Royal Infirmary, Edinburgh, UK

SUMMARY Investigations into the immunological functions of three patients with chronic mucocutaneous candidiasis were carried out. Phagocytosis of Candida albicans, nitroblue tetrazolium dye reduction, complement, and immunoglobulin levels were normal. Candidacidal assays using the neutrophils of the patients in autologous serum showed significant decreases below normal levels. This decrease in kill could be corrected by incubating the patients' cells in normal control or human AB serum. Cross-over serum studies also showed that the patients' sera had inhibitory effects on the candidacidal capacity of normal neutrophils. These changes in kill were related to candida antibody levels.

Chronic mucocutaneous candidiasis is a disorder characterised by Candida albicans infection in skin, nail, and mucous surfaces and defective cell-mediated immunity. Defective candidacidal activity by polymorphonuclear leucocytes has seldom been recognised, ${ }^{1}$ although defective intracellular killing by monocytes has been reported, ${ }^{2}$ and it has been suggested that the defect is due to a serum-dependent inhibitor. ${ }^{2}$

\section{Patients and methods}

Neutrophil function was investigated in three patients ( $\mathrm{KH}, \mathrm{JH}, \mathrm{MR})$ with chronic mucocutaneous candidiasis using a micro method for the estimation of killing and phagocytosis of C. albicans. ${ }^{3}$ Antibody levels against $C$. albicans were determined by an indirect haemagglutination test (Roche). Other laboratory investigations included a nitroblue tetrazolium reduction test, and measurement of complement and immunoglobulin levels. ${ }^{4} \mathrm{AB}$ serum was obtained from an untransfused male donor, and

Received for publication 29 October 1979 control neutrophils and sera from normal healthy individuals.

\section{Results}

In all three patients, complement and immunoglobulin levels were normal. Nitroblue tetrazolium reduction test values, both stimulated with Escherichia coli endotoxin and unstimulated, were also normal.

Phagocytosis of $C$. albicans in both autologous and $\mathrm{AB}$ serum was normal in all three patients. The phagocytic index, estimated from the total numbers of phagocytic cells containing $C$. albicans, was normal in autologous and AB serum (Tables 1 and 2). The intracellular killing of $C$. albicans by control neutrophils in the presence of patients' sera was depressed in all three cases, when compared with that of the same neutrophils in either autologous or AB serum (see Figure). Normal ranges for the per cent of candida phagocytosed and killed in autologous and in $A B$ serum have been reported previously. ${ }^{3}$ Appropriate controls of heat-killed and viable candida in autologous or $A B$ serum, in the

Table 1 Effect of serum on control neutrophils

\begin{tabular}{|c|c|c|c|c|c|c|}
\hline \multirow[t]{2}{*}{ Subiect } & \multicolumn{2}{|l|}{ Control serum } & \multicolumn{2}{|l|}{$A B$ serum } & \multicolumn{2}{|l|}{ Patient serum } \\
\hline & $\%$ Phagocytosis & $P$ index & $\%$ Phagocytosis & $P$ index & $\%$ Phagocytosis & $P$ index \\
\hline
\end{tabular}


Table 2 Effect of serum on patient neutrophils

\begin{tabular}{|c|c|c|c|c|c|c|}
\hline \multirow[t]{2}{*}{ Subject } & \multicolumn{2}{|l|}{ Control serum } & \multicolumn{2}{|l|}{$A B$ serum } & \multicolumn{2}{|l|}{ Patient serum } \\
\hline & $\%$ Phagocytosis & $P$ index & $\%$ Phagocytosis & $P$ index & $\%$ Phagocytosis & $P$ index \\
\hline $\begin{array}{l}\text { KH } \\
\text { JH } \\
\text { MR }\end{array}$ & $\begin{array}{l}97 \\
97 \\
98\end{array}$ & $\begin{array}{l}2 \cdot 1 \\
2 \cdot 7 \\
2 \cdot 2\end{array}$ & $\begin{array}{l}98 \\
97 \\
97\end{array}$ & $\begin{array}{l}2 \cdot 0 \\
2 \cdot 7 \\
2 \cdot 4\end{array}$ & $\begin{array}{l}\text { NT } \\
98 \\
98\end{array}$ & $\begin{array}{l}\text { NT } \\
2 \cdot 1 \\
2 \cdot 5\end{array}$ \\
\hline
\end{tabular}

NT $=$ not tested.

absence of neutrophils, were included in the estimation of kill. Cross-over studies, carried out simultaneously for the detection of serum-associated defects, showed that there was also an increase in kill when patients' cells were incubated in control or AB serum, compared with that of patients' cells in autologous serum (see Figure).

The candida antibody titres for the three patients were as follows: $\mathrm{KH}, 1: 1280 ; \mathrm{JH}, 1: 640 ; \mathrm{MR}, 1: 160$. The level of antibody is inversely related to candidacidal activity; the higher the antibody titre, the more inhibitory the chronic mucocutaneous candidiasis serum.

\section{Discussion}

The cross-over serum studies used to assess serumassociated defects of candidacidal activity suggest that there is some inhibitory factor in the serum of these three patients with chronic mucocutaneous candidiasis. This candidacidal defect can be corrected by incubating patients' cells in 'normal' serum, either control or AB serum. These observations confirm previous reports of an inhibitor of intracellular killing of $C$. albicans by polymorphonuclear leucocytes. $^{2}$

Normal values for the phagocytic indices of all three patients exclude a phagocytic or opsonic defect as a cause of decreased candidacidal activity.

Haemagglutination titres of up to $1: 40$ are considered normal in adults, whereas titres of over $1: 60$ are an indication of candida infection. Our evidence suggests that there is some relationship between the levels of candida antibodies and the inhibitor in chronic mucocutaneous candidiasis serum. This is unusual since antibodies are involved in the opsonisation and digestion of microorganisms and have been shown to mediate cytotoxic mechanisms. It may be that an inappropriate class or subclass of antibody is being produced and this inhibits efficient elimination of $C$. albicans in vivo. An analogous situation exists for antibody-coated erythrocytes where the IgG subclass determines whether or not these cells will be haemolysed and removed by the reticuloendothelial system. ${ }^{5}$

Further characterisation of the serum inhibitors

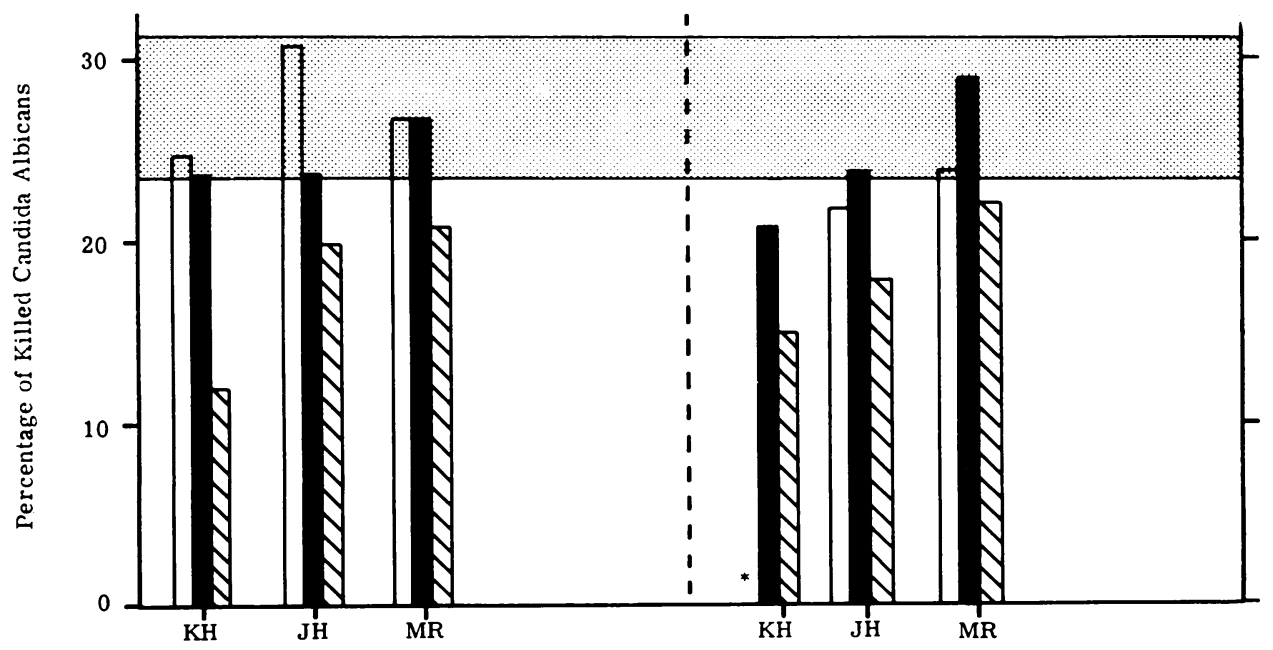

Effect of serum on the candidacidal activity of control (left) and patient (right) neutrophils (shaded area $=$ observed normal range): $\square$ control serum; $\square$ AB serum; Nㅐ patient serum. ${ }^{*}$ not tested. 
is necessary in order to assess their biological and clinical significance in chronic mucocutaneous candidiasis. We have found similar inhibitory factors in the sera of several patients with recurrent infections, and these are also currently under investigation.

\section{References}

${ }^{1}$ Lawton JWM, Costello C, Barclay GR et al. The effect of transfer factor on neutrophil function in chronic mucocutaneous candidiasis. Br J Haematol 1978; 33:137-42.

2 Van der Meer JWM, Leijh PCJ, Van den Barselaar H, Van Furth R. Functions of phagocytic cells in chronic mucocutaneous candidiasis. Br Med J 1978;1:147-8.

${ }^{3}$ Wood SM, White AG. A micro method for the estima- tion of killing and phagocytosis of Candida albicans by human leucocytes. J Immunol Methods 1978; 20:43-52.

${ }^{4}$ Urbaniak SJ, White AG, Barclay GR, Wood SM Kay AB. Tests of immune function. In: Weir DM, ed. Handbook of Experimental Immunology 3rd ed. Oxford: Blackwell Scientific Publications, 1978:1-37.

${ }^{5}$ Van der Meulen FW, Van der Hart M, Von dem Borne AEGK, Engelfriet CP, Van Loghem JJ. The role of adherence to human mononuclear phagocytes in the destruction of red cells sensitized with non-complement binding IgG antibodies. Br J Haematol 1978; 38:541-9.

Requests for reprints: to Dr SJ Urbaniak, Immunology Division, Regional Blood Transfusion Centre, Royal Infirmary, Edinburgh EH3 9HB, UK. 